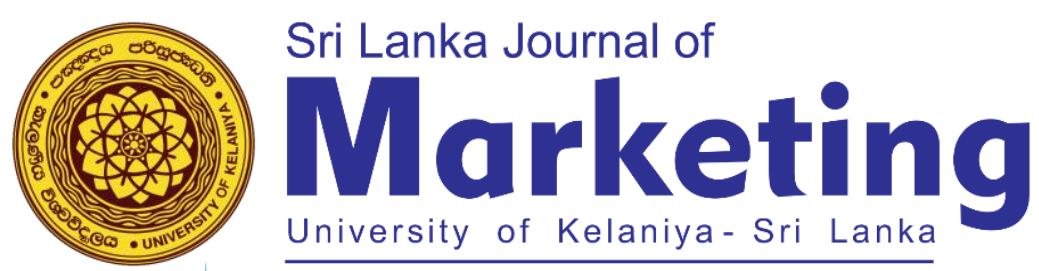

\title{
Customers' Role in Co-Creating Value at Self-Service Technologies: From Role Theory Perspective
}

Galdolage, B. S.
University of Sri Jayewardenepura, Sri Lanka
sandamali@ sjp.ac.lk

\begin{abstract}
Technological maturity brings both the organizations and customers into a digital era where organizations provide its service fully or partly through technological platforms, letting customers to perform by themselves without having direct interaction with the organization's employees. This transforms customers' role into more 'active' to be a collaborative value creator than be a passive recipient of the value produced by the organization. Organizations' role also converts from 'provider' of the value to the 'value facilitator', who offer value prepositions for customers' co-creation process.

Though both the customers' and business organizations' roles have been changed in the current business context, the scholarly attention given to understand this transformation is very rare. In such a backdrop, this study aims at understanding customers' role in co-creating value at SSTs using the foundations of the Role Theory.
\end{abstract}

Centered on the positivistic approach, this research carried out a quantitative survey distributing selfadministered questionnaires among 600 customers chosen based on non-probabilistic convenience sampling method. The study found significant positive impacts of 'role script', 'role performance' and 'role set', and insignificant effect of 'role congruence' on customer value co-creation in SSTs.

The study theoretically contributes to enhancing the knowledge on customer value co-creation in selfservice technologies from role theory perspective, while practically helps business organizations to understand customers' role well and design SSTs which match with the customers' expectations.

Keywords: Customer, Role Theory, Self-Service Technologies, Value Co-Creation 


\section{INTRODUCTION}

Self-Service Technologies are a natural outcome of technological maturity; thus, technologically incorporated service operations are becoming the norm of today's business practices. Additionally, business organizations use SSTs as a solution for the increasing labor cost (Meuter and Bitner, 1998). Similarly, the efficiency of transactions backed by time saving, cost savings and less human errors led businesses to convert their service encounters into technologically incorporated services (Meuter and Bitner, 1998).

It provides the opportunity for customers to use full or part of an organization's service, by electronic means at arm's length (Lorenzo-Romero et al., 2021) without direct contacts with the organization's service staff (Meuter and Bitner, 1998, Verhoef et al., 2009). SSTs which range from Automated Teller Machines (ATMs) to self-checkouts at airports (Meuter et al., 2000), provide an unimaginable convenience and independence to the customer.

Customers' role in SST is more active (Hilton et al., 2013) and most of the time needs to perform transactions on their own (Hsu et al., 2021). In this new business norm, business organizations are viewed as value facilitators whose role is largely limited to provide value propositions. When customers accept such value propositions (e.g.: SSTs), and decide to integrate their resources (skills, knowledge, credit/debit cards, information) with it, collaborative value creation takes place. Here, customers' role becomes more active (Knote et al., 2021) and known as the creator of his own value. If customers cannot perform their role as a collaborative value creator, they will end up with failures which results in value co-destructions.

Further, everybody will not perceive the SSTs in the same way (Lin and Mattila, 2021) and accept for their transactions (Liljander et al., 2006). People will not use self-service technologies if they realize it as uncomfortable and not useful (Meuter et al., 2005). If SSTs are properly designed, even a technologically illiterate person can perform their role comfortably with or without a guidance from the organization (Quinn et al., 1990). Thus, business organizations should pay attention to understand customers' role in SSTs (Guan et al., 2021) and propose suitable value prepositions to facilitate their co-creation process.

However, there has been little exploration on consumers' role in performing SSTs in academic research (Verhoef et al., 2009). Thus, this study aims at understanding the customers' role as the value co-creator in SSTs using the lens of 'Role Theory'. Accordingly, it examines the impact of 'role script', 'role performance', 'role congruence' and 'role set' on customer value co-creation in SSTs. 


\section{CONCEPTUAL FOUNDATION}

This section begins explaining self-service technologies and then moves to describe customers' role as well as service providers' role in self-Service Technologies. Next, the study introduces role theory and followed by a description on the customer's role as a 'value co-creator' in SSTs.

\subsection{Customer's Role in SSTs}

In the Goods-Dominant Logic (GD logic) value has been traditionally recognized as an non-interactive form of exchange of products or services to customers who are passive receivers of outcomes (Hunt, 1976). With the evolution of the Service-Dominant Logic (SD logic), customers' active role in creating value came to the discussions. It became a transition of previously recognized roles of customers from passive to more active (Cova et al., 2011).

The active role of the customer is explained in SD logic as "customer is always a co-creator of value" (FP6) (Vargo and Lusch, 2008). Additionally, customers have been recognized as the 'beneficiary' who is the recipient of a value collaboratively created by him/herself. Customer value creation has been recognized as a "dynamic, interactive, nonlinear and unconscious processes"(Payne et al., 2008:86). Furthermore, the process of customer value co-creation is challenging to understand, since their roles become more active and changing throughout the process (Chan et al., 2010, Gallan et al., 2013).

Customer Dominant Logic (C-D logic) also explains the customer-centric view in co-creation (Heinonen et al., 2010), and gives foundations to realize co-creation takes place between customer to customer interfaces ( $\mathrm{C} 2 \mathrm{C}$ co-creation). The $\mathrm{C}$-D logic suggests for service organisations to make an effort to uncover active customer engagement in value co-creation (Rihova et al., 2013), which is a vibrant and multi-layered process (Rihova et al., 2013).

Bendapudi and Leone (2003) distinguish different roles of customers in co-creation, taking place through emotionally and physically engaging in product designing, producing, self-service, using etc. According to Preikschas et al. (2017), customers who have relational, adaptation and innovation abilities can be successful in value co-creation compared to others.

Galdolage (2018) found that the main five forms of customer value co-creation take place in self-service technologies through collaborative learning, co-production, cooperation, connections with service providers and correcting errors. Six roles of customers who perform in co-creating value were recognized in the literature as; team manager, isolate controller, partner, spiritualist, adaptive realist and passive compliant (McColl-Kennedy et al., 2009). Prebensen and Xie (2017) acknowledge the importance of customer psychological participation in value co-creation especially in creating value perceptions. Terblanche (2014:3) suggests four things to study to realize customer co-creation as "stages 
they go through when participating, what motivates them to participate, their roles in co-creation, and their participation styles".

Customers engage with value co-creating activities through changing their roles to active participants, improving their capabilities which are needed for the collaborative process and contributing their resources to the process of value creation (Michel et al., 2008). Merz et al. (2018) found the importance of 'customer-owned resources' such as their skills, knowledge, creativity, connectedness and their motivation on customer value co-creation.

Value co-creation essentially follows social structures in which the business organizations and customers adopt certain social positions (Edvardsson et al., 2011). In such, the customer's position is changing overtime and in different situations, and therefore complex to understand (Cova and Dalli, 2009, Saarijärvi et al., 2013). Both the business organization and customers are the owners of resources (physical resources, skills, knowledge etc.) who integrate them to activate the value co-creation process (Lusch and Vargo, 2014). Here, having better understanding of each other's role becomes important (Epp and Price, 2011, Broderick, 1998) to prevent potential role conflicts (Moeller et al., 2013).

According to Prahalad and Ramaswamy (2004:1) people who are "informed, networked, empowered, and active" can be successful in value co-creation compared to others. As Cova et al. (2015) mentioned, customers would become 'unpaid employees' through voluntary contributions with business organisations. Since business organisations can not create value (Vargo and Lusch, 2008); rather than offering value propositions (Skålén et al., 2015), value exclusively lies in the customer's domain (Grönroos, 2006). Therefore, the role of the customer is central to the value co-creation process (Aarikka-Stenroos and Jaakkola, 2012). This study aims at understanding the role performed by the customers in co-creating value at self-service technologies.

\subsection{Service Provider's Role in Value Facilitation}

Service providers' role also has changed from 'provider' of value to the 'facilitator' who provides necessary resources to facilitate the customer value co-creation process (Grönroos, 2008). In here, business organizations need to develop value propositions, which are the foundation for the value to be used by customers. If customers accept these value propositions, and add their resources (skills, knowledge and other needed physical resources), value co-creation takes place (Grönroos, 2006).

In this competitive business environment, service providers should provide superior value propositions compared to the other competitors in the market. As Payne et al. (2008) note, superiority of the value propositions affects customers' co-creation ability. Thus, business organizations should understand the customers role very well and provide value propositions to match with customer value expectations and role performance (Normann, 2001).This market offering works as a connector between the 
organisation and the customer (Lusch et al., 2010). Therefore, if business organizations offer smart value propositions, it will be able to shape customers' value perception into a more positive way (Frow et al., 2015:328).

As Sandström et al. (2008) mentioned, business organizations can offer two types of value propositions namely, 'Functional value propositions' and 'Emotional value propositions'. However, according to Merrilees (2016) customer engagement is relatively low in functional value propositions and therefore, these two types result in different kinds of customer engagement and different levels of co-creation.

As Grönroos and Voima (2013) elaborate, if the business organizations limits its role only in to facilitate customer value co-creation process, a healthy relationship between the firm and the customer is critical (Jaworski and Kohli, 2006, Payne et al., 2009), which is needed to achieve customer loyalty (Yi and Gong, 2013). Terblanche (2014:3) recognize organization's role as "creating environments that facilitate the customer co-creation", which are interactive in nature (Payne et al., 2008) and require employee's emotionally engaged (Lee et al., 2017).

This study views the business organisation as a value facilitator who offers value propositions (SSTs and other needed resources) to support customer value co-creation process in technological interfaces.

\subsection{Customers' Vs Organizations' Role in Co-Creating Value at SSTs}

Grönroos (2008:306) differentiate supplier's and customer's role in value creation saying that the business organization becomes value facilitator while customer converts into value creator in this new service environment.

Table 1: Value facilitation model

\begin{tabular}{ll}
\hline Supplier & Customer \\
\hline Value facilitator by providing customers & Value creator during value-generating processes \\
with a foundation for their value creation in & (consumption) where other (necessary) resources \\
the form of resources (goods, services, & available to customers and skills held by them \\
information or other resources) & (customer's value foundation) are added and where \\
& value fulfilment takes place
\end{tabular}

Source: Grönroos (2008:306)

Similarly, Vargo et al. (2008:148) distinguished the roles of the organization and customers by comparing the change from Goods-dominant perspective to Service-Dominant perspective. Though previously, business organizations used to produce and distribute the value to the customer, in this new service environment it supports the value co-creation process. Customers' role also changed from using and destroying value to co-create value through integrating resources. 
Table 2: Customers' role Vs Organization' role

Old perspective

Role of firm $\quad$ Produce and distribute value

\section{New Perspective}

Propose and co-create value, provide service

Source: Adapted from Vargo et al. (2008:148)

\subsection{Role Theory}

Role theory is based on the foundations of 'social penetration theory', and 'social exchange theory' (Broderick, 1998). It is heavily used in marketing literature, particularly to understand the customers' and service providers' role in the service encounters (Solomon et al., 1985, Broderick, 1998, Brown et al., 2007, Lysonski and Johnson, 1983). Further the role theory is used to understand the behaviors of different customer communities such as online communities and brand communities (Gleave et al., 2009, Chalmers, 2003).

The role theory can be applied to understand the 'client-provider' interactions in services marketing context (Gronroos, 1990). It is based on the notion that, normally everybody adopts, the social interactions primarily determined by their roles (Goffman, 1959). Due to the social roles, people know their expected behaviour in different settings. A 'script' is a person's knowledge about the sequence of events expected in a specific setting. Thus, role script should be very clear and provides the chance to understand the behaviour of different roles (Broderick, 1998).

Individuals learn through their roles and especially their confidence about the performing role lead to satisfaction of performance which is known as 'role validation'. Some roles are more individual than other roles (Solomon et al., 1985) and the role of consumer at the technological interface also can be recognized as a much more individualistic role. Some of the findings of Solomon is highly relevant to the application of role theory in value co-creation at SSTs which emphasized that the service setting is highly responsible for the successful enactment of the consumer (Solomon et al., 1985). Hence, necessary direction, navigations, and advices are important in this phenomenon which are necessary to the consumer to perform their role well. The elements of the role theory are described as follows (Broderick, 1998). 
Role set: $\quad$ Set of behaviours which are established through working relationships and understanding of role commitments in service provisions. Role set is "the "complement of social relationships in which persons are involved because they occupy a particular social status." It further describes the variety of roles and relationships a person has.

Role script Role behaviours expected, enacted, or developed within client-service provider interface. It basically consists of the expected and appropriate role behaviours which emerge between two parties in a social exchange. Because of social roles, people tend to know what behaviour is expected of them in specific, familiar settings. A script is a person's knowledge about the sequence of events expected in a specific setting (Schank \& Abelson, 1977).

Role It proposes that mutual understanding of role expectations and behaviour is an congruence important aspect of good service performance. Job role congruence describes the match between a job role and another social role an individual hold.

Role Evaluation and experience of current role by provider. Cumulative set of actions Performance interactions, activities under-taken by the customer in their fulfilment of service role

\subsection{Conceptual framework}

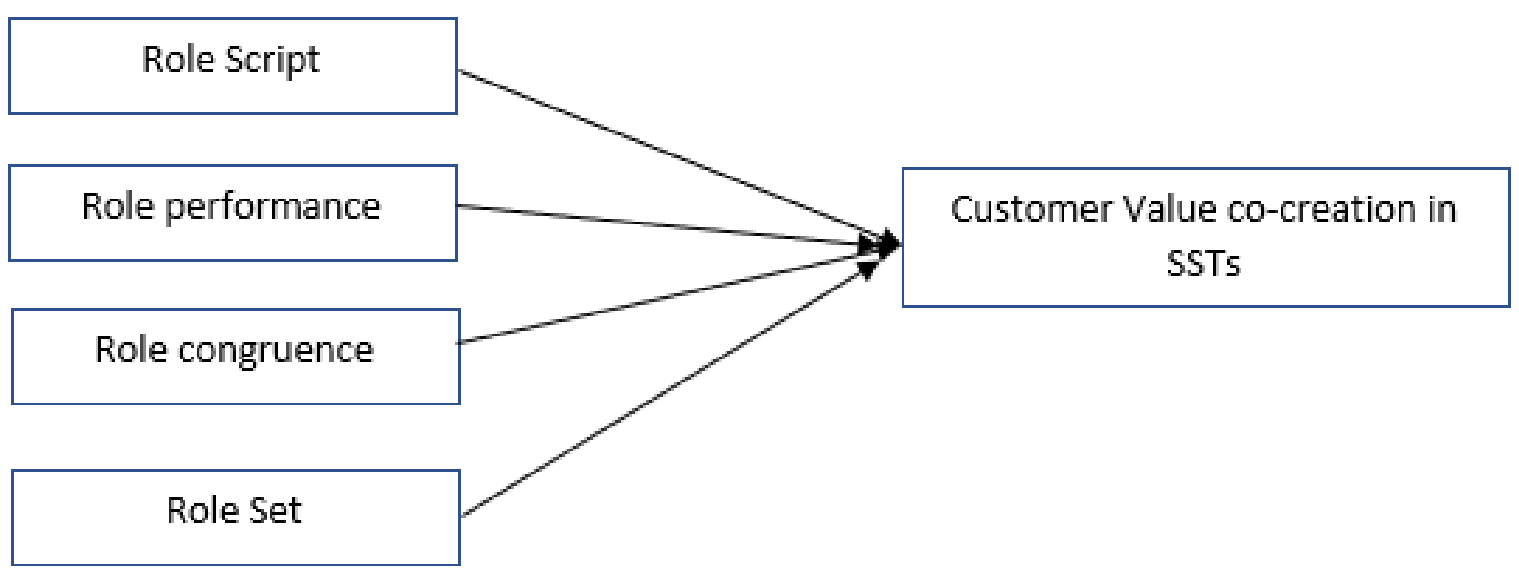

Using the foundations of role theory, this study examines the impact of role set, role performance, role congruence and role script on customer ability in co-creating value at SSTs. Accordingly following hypotheses were developed. 
$\mathrm{H} 1 \rightarrow$ Clear 'role scripts' positively impact on customer value co-creation in SSTs.

$\mathrm{H} 2 \rightarrow$ Customer's ability in 'role performance' positively impact on customer value co-creation in SSTs.

H3 $\rightarrow$ Congruence of customers' roles in different SSTs positively impact on customer value cocreation in SSTs.

$\mathrm{H} 4 \rightarrow$ Well established 'role set' positively impact on customer value co-creation in SSTs.

\section{METHODOLOGY}

The main purpose of this study is to examine the customers' role in value co-creation in SSTs. Based on the 'role theory' the study examines the impact of 'role script', 'role performance', 'role congruence', and 'role set' on customer value co-creation in SSTs. Positioning the study within the positivistic research paradigm, a quantitative survey was carried out distributing self-administered questionnaires among 600 people chosen based on convenience sampling method.

Constructs were operationalized through a rigorous literature review and scales were developed with five-point Likert scale ranging from $1=$ strongly disagree to $5=$ strongly agree. Expert opinions were taken with the aim of further improving the research instrument which was followed by a pilot study.

Data were checked against missing values and outliers. Multivariate assumptions were mainly checked through normality. Internal consistency of the items was measured using Cronbach's alpha and validity was ensured through content validity, construct validity and discriminant validity. Exploratory factor analysis was carried out to ensure the uni-dimensionality nature of the data. Finally, data were analyzed using descriptive statistics, correlation and regression.

\subsection{Data Preparation for Analysis}

Upon receiving the questionnaires, they were checked for completeness and 23 were eliminated with serious missing values(Glas and Pimentel, 2008). As suggested by Hair et al (2016), a small number of missing values which were recognised as random were replaced with the median. Subsequently, outliers were checked using boxplots and found 31 occurrences in eight variables. As suggested by Hair et al. (2016), the researcher herself closely observed those variables and recognized them as true expressions of the respondents rather than typical outliers, therefore decided to keep in the data set.

Normality was checked using skewness and kurtosis. As recommended in the literature skewness and kurtosis values are preferred to be established in between -1.96 and +1.96 which this study satisfied the conditions (Trochim and Donnelly, 2006; Field, 2009; George and Mallery, 2010; Gravetter and 
Wallnau, 2014). Exploratory Factor Analysis (EFA) was carried out to identify the uni-dimensionality of the measures and all the items indicated factor loadings above 0.5 as shown in the table 3 .

Table 3: Factor Analysis Matrix

\begin{tabular}{|c|c|c|c|c|c|c|}
\hline Items & Component 1 & Component 2 & Component 3 & Component 4 & & $\begin{array}{c}\% \text { of } \\
\text { Variance }\end{array}$ \\
\hline ROSC1 & 0.892 & & & & & $86.67 \%$ \\
\hline ROSC2 & 0.960 & & & & & \\
\hline ROSC3 & 0.940 & & & & & \\
\hline ROPF1 & & 0.823 & & & & $64.74 \%$ \\
\hline ROPF2 & & 0.897 & & & & \\
\hline ROPF3 & & 0.879 & & & & \\
\hline ROPF4 & & 0.825 & & & & \\
\hline ROPF5 & & 0.739 & & & & \\
\hline ROPF6 & & 0.633 & & & & \\
\hline ROCN1 & & & 0.702 & & & $62.68 \%$ \\
\hline ROCN2 & & & 0.816 & & & \\
\hline$\overline{\mathrm{ROCN} 3}$ & & & 0.850 & & & \\
\hline ROCN4 & & & 0.778 & & & \\
\hline ROCN5 & & & 0.805 & & & \\
\hline ROSE1 & & & & 0.870 & & $63.54 \%$ \\
\hline ROSE2 & & & & 0.881 & & \\
\hline ROSE3 & & & & 0.610 & & \\
\hline COVC1 & & & & & 0.904 & $84.64 \%$ \\
\hline COVC2 & & & & & 0.918 & \\
\hline COVC3 & & & & & 0.938 & \\
\hline
\end{tabular}

Source: Survey Data

\subsection{Test of Validity}

Validity can be assessed by examining the content validity, criterion validity, and construct validity (Sekaran, 2006, p.203). This study ensures the content validity since all the indicators (independent variables and a dependent variable) have been taken from the well-established literature. Convergent validity was ensured by checking factor loadings, squared multiple correlations, average variance extracted, reliability etc.

Table 4: Summary of Convergent Validity Results

\begin{tabular}{lllllll}
\hline Variable Name & KMO & $\begin{array}{l}\text { Sphericity } \\
\text { test }\end{array}$ & for Average & $\begin{array}{l}\text { Composite } \\
\text { Variance }\end{array}$ & $\begin{array}{l}\text { Cronbach's } \\
\text { Reliability } \\
\text { Alpha }\end{array}$ & $\begin{array}{l}\text { Discriminant } \\
\text { Validity }\end{array}$ \\
\hline
\end{tabular}




\begin{tabular}{|c|c|c|c|c|c|c|}
\hline & & $\begin{array}{l}\text { Bartlett } \\
\text { (Sig) }\end{array}$ & $\begin{array}{l}\text { Extrac } \\
\text { (AVE) }\end{array}$ & & & \\
\hline Role script(ROSC) & .713 & .000 & 0.866 & 0.951 & .920 & Ensured \\
\hline $\begin{array}{ll}\text { Role } & \text { Performance } \\
\text { (ROPF) } & \end{array}$ & .864 & .000 & 0.799 & 0.915 & .882 & Ensured \\
\hline $\begin{array}{ll}\begin{array}{l}\text { Role } \\
(\mathrm{ROCN})\end{array} & \text { Congruence } \\
\end{array}$ & .742 & .000 & 0.626 & 0.893 & .848 & Ensured \\
\hline Role set (ROSE) & .589 & .000 & 0.638 & 0.835 & .691 & Ensured \\
\hline $\begin{array}{ll}\text { Value } & \text { Co-creation } \\
(\text { COVC) } & \end{array}$ & .745 & .000 & 0.846 & 0.943 & .909 & Ensured \\
\hline
\end{tabular}

Source: Survey outcome \& own computation

KMO values for the five variables shown in table 4 are greater than 0.5 , Sphericity test for Bartlett is also significant. All the composite reliabilities exceeded 0.7. The AVE values also are over 0.5 suggesting the convergence validity of the scales is of high quality. Cronbach's alpha coefficients of role script', 'role performance', 'role congruence', and 'role set' on customer value co-creation were $0.920,0.882$, and $0.848,0.691$ and .909 respectively, indicating internal consistency of the data.

\subsection{Hypothesis Testing}

Examine the impact of role script', 'role performance', 'role congruence', and 'role set' on customer value co-creation in SSTs.

This study aims at examining the impact of role script', 'role performance', 'role congruence', and 'role set' on customer value co-creation in SSTs. Thus, a linear regression analysis was performed to check this hypothesis.

According to the findings, role script', 'role performance', 'role congruence', and 'role set' together explain the $53 \%$ of the customer role in value co-creation at SSTs.

Table 5: Model summary

\begin{tabular}{llllll}
\hline Model & $\mathrm{R}$ & R Square & Adjusted R Square & $\begin{array}{l}\text { Std. } \\
\text { Estimate }\end{array}$ & of the \\
& & & .61942 \\
\hline 1 & $.727^{\mathrm{a}}$ & .529 & .524 &. \\
\hline \multicolumn{2}{l}{ a. Predictors: (Constant), Role-set, Role-congruence, Role-script, Role performance } \\
\hline
\end{tabular}

According to the table 5, model became significant at $(\mathrm{f}=113.791, \mathrm{df}=4, \mathrm{p}<0.05)$, suggesting that analysis would generate reliable findings. 
Table 6: ANOVA table

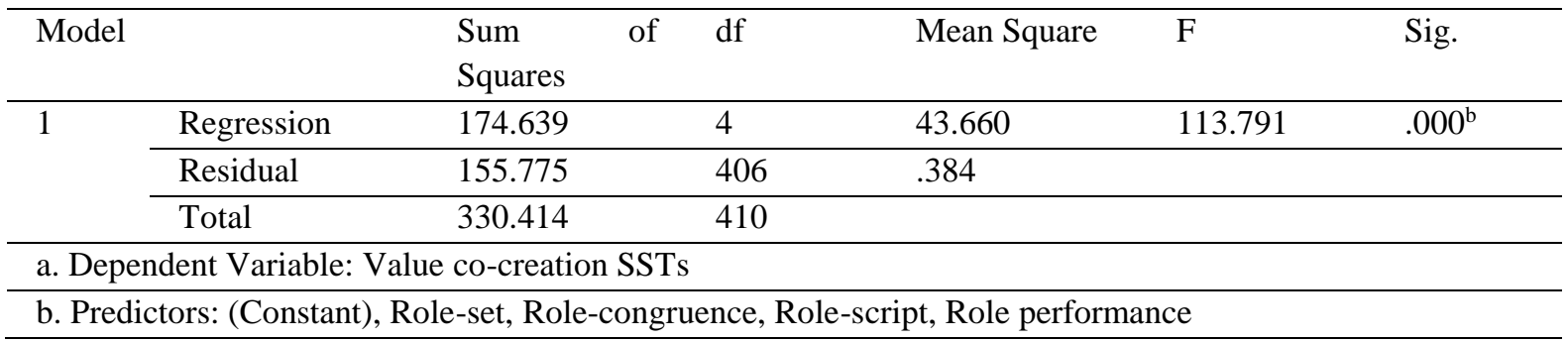

Table 6 suggests a moderate positive significant impact $(\beta=.419, \mathrm{p}<0.05)$ of 'role script', weak positive significant impact of 'role performance' $(\beta=.259, \mathrm{p}<0.05)$, insignificant impact of 'role congruence' ( $\beta=.051, \mathrm{p}<0.372)$, weak positive significant impact of 'role set' $(\beta=.274, \mathrm{p}<0.05)$, on customer role in value co-creation in SSTs.

Table 7: Coefficients

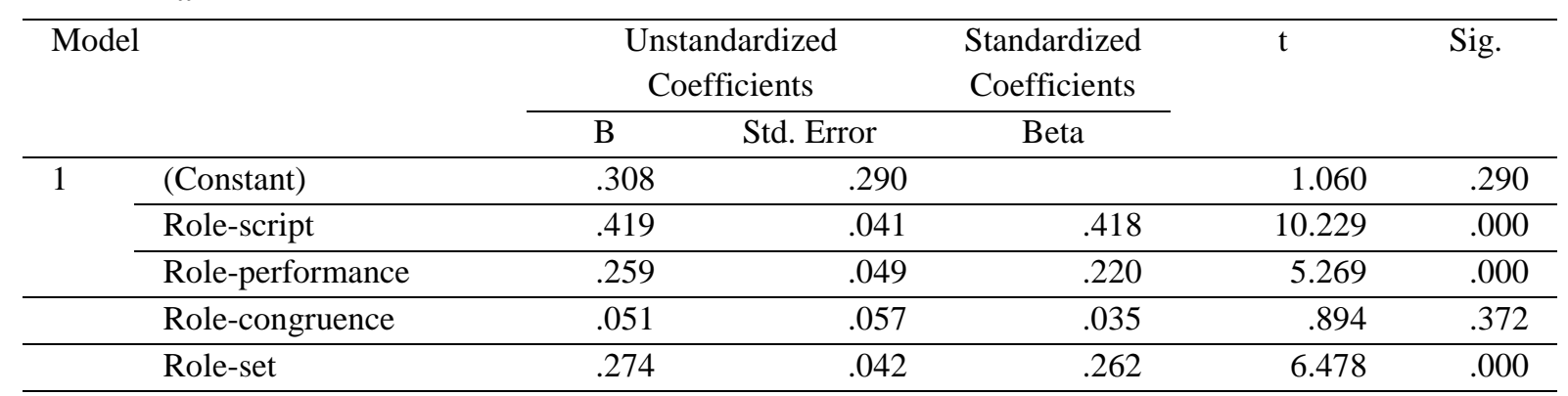

a. Dependent Variable: Value co-creation SSTs

Source: Survey Data

\section{DISCUSSION}

This study attempted to understand the impact of role theory dimensions (role script, role performance, role congruence, role set) on customers' role in value co-creation. The study found a positive significant impact $(\beta=.419, \mathrm{p}<0.05)$ of 'role script' on customer value co-creation in SSTs. It suggests that when the consumer is expected and aware on exact role and sequence of activities that he/she needs to play in SST settings, it enhances their ability in co-creating value (Schank \& Abelson, 1977). Additionally, findings reveal a positive significant impact of 'role performance' $(\beta=.259, p<0.05)$, indicating that completing cumulative set of actions, interactions and activities appropriately result in positive outcomes (Gronroos, 1990). However, the study found an insignificant impact of 'role congruence' ( $\beta=.051, \mathrm{p}<0.372)$, while a positive significant impact of 'role set' $(\beta=.274, \mathrm{p}<0.05)$, found on customer role in value co-creation in SSTs. It implies that customers, understanding of role commitments in service provisions result in positive outcomes such as value co-creation in SSTs.

Binding to the paucity in the literature on understanding value co-creation in SSTs, particularly, application of role theory in understanding customers' role in technological platforms, the study extends the comparison of the outcomes with the existing body of knowledge. Kelly et al. (2017) identify six 
customer roles in SSTs as 'convenience seeker, motivated worker, judge, enforced worker, unskilled worker, and assistance provider', under two categories as 'voluntary roles' and 'enforced roles. An 'enforced worker' is forced' to perform some tasks and controlled by the organization. Therefore, such customers are dissatisfied and disloyal to the organization.

Customers' role in value co-creation is found to be essential, (Grönroos and Ravald, 2011) yet more dynamic (Cova et al., 2011) process. Further it is complex and changing over time and in different contexts (Cova and Dalli, 2009; Saarijärvi et al., 2013). Both the customers and service providers are performing their relevant roles as resource integrators and the owners of operant resources(Lusch and Vargo, 2014). To perform well in the co-creation process, each party should understand the dynamic, interactive nature of each other's roles (Epp and Price, 2011; Broderick, 1998) which could prevent the potential role conflicts (Moeller et al., 2013). Both the parties should learn and respect each other's role.

The researchers found some roles as more individual (Solomon et al., 1985) such as customer's role as SSTs. Service setting (in here provision of SSTs) is highly responsible for the successful enactment of the consumer value co-creation process (Solomon et al., 1985). Hence, necessary direction, navigations and advice are important in this phenomenon which are necessary to the consumer to perform their role well.

\section{CONCLUSION RECOMMENDATIONS FUTURE RESEARCH DIRECTIONS}

This study focused on understanding the customers' role in co-creating value in self-service technologies. It used role theory as the theoretical foundation in the attempt of understanding the study matter. The study found the role script, role performance and role set as having significant positive impact on customer value co-creation in SSTs. According to my limited understanding, none of the research particularly understands the customer role of value co-creation in SSTs from the role theory perspective. Hence, this study contributes to theory building, enhancing the understanding of using the role theory to realize the customers' role in value co-creation perticulalrly in SST context.

On practical ground, study provides insights for service providers who are currently providing or planning to provide or transform their existing services into self- service technology platforms to understand the role performed by customers. Understanding customers' role well would bring benefits to service organizations in designing and delivering customised user-friendly services which finally bring competitive advantages to the organization.

It provides direction to future researchers to investigate customer-service provider interactions exploring roles of both service provider and the customer in interactive value co-creation context. 


\section{ACKNOWLEDGEMENT}

Author would like to thank the anonymous reviewers for their excellent suggestions in completing this study.

\section{CONFLICT OF INTEREST}

The author declares no conflicts of interest.

\section{REFERENCES}

Aarikka-Stenroos, L. and Jaakkola, E. (2012), "Value co-creation in knowledge intensive business services: A dyadic perspective on the joint problem solving process". Industrial Marketing Management, Vol. 41 No 1, pp. 15-26.

Bendapudi, N. and Leone, R. P. (2003), "Psychological Implications of Customer Participation in Co-Production". Journal of Marketing, Vol. 67 No 1, pp. 14-28.

Broderick, A. J. (1998), "Role theory, role management and service performance". Journal of Services Marketing, Vol. 12 No 5, pp. 348-361.

Brown, J., Broderick, A. J. and Lee, N. (2007), "Word of mouth communication within online communities: Conceptualizing the online social network". Journal of Interactive Marketing, Vol. 21 No 3, pp. 2-20.

Chalmers, P. A. (2003), "The role of cognitive theory in human-computer interface". Computers in Human Behavior, Vol. 19 No 5, pp. 593-607.

Chan, K. W., Yim, C. K. and Lam, S. K. (2010), "Is Customer Participation in Value Creation a Double-Edged Sword? Evidence from Professional Financial Services Across Cultures". Journal of Marketing, Vol. 74 No 3, pp. 48-64.

Cova, B. and Dalli, D. (2009), "Working consumers: the next step in marketing theory?". Marketing Theory, Vol. 9 No 3, pp. 315-339.

Cova, B., Dalli, D. and Zwick, D. (2011), "Critical perspectives on consumers' role as 'producers': Broadening the debate on value co-creation in marketing processes". Marketing Theory, Vol. 11 No 3, pp. 231-241.

Cova, B., Pace, S. and Skålén, P. (2015), "Brand volunteering:Value co-creation with unpaid consumers". Marketing Theory, Vol. 15 No 4, pp. 465-485.

Edvardsson, B., Tronvoll, B. and Gruber, T. (2011), "Expanding understanding of service exchange and value cocreation: a social construction approach". Journal of the Academy of Marketing Science, Vol. 39 No 2, pp. 327-339.

Epp, A. M. and Price, L. L. (2011), "Designing Solutions Around Customer Network Identity Goals". Journal of Marketing, Vol. 75 No 2, pp. 36-54.

Field, A. (2009). Discovering Statistics Using SPSS, SAGE Publications.

Frow, P., Nenonen, S., Payne, A. and Storbacka, K. (2015), "Managing Co-creation Design: A Strategic Approach to Innovation". British Journal of Management, Vol. 26 No 3, pp. 463-483. 
Galdolage, B. S. 2018. Value co-creation intention, practices and experience in self-service technologies. $\mathrm{PhD}$, University of Hull.

Gallan, A. S., Jarvis, C. B., Brown, S. W. and Bitner, M. J. (2013), "Customer positivity and participation in services: an empirical test in a health care context". Journal of the Academy of Marketing Science, Vol. 41 No 3, pp. 338-356.

George, D. and Mallery, M. (2010). SPSS for Windows Step by Step: A Simple Guide and Reference, Boston, Pearson.

Glas, C. a. W. and Pimentel, J. L. (2008), "Modeling nonignorable missing data in speeded tests". Social Science, Vol. 68 No 6, pp. 907-922.

Gleave, E., Welser, H. T., Lento, T. M. and Smith, M. A. A Conceptual and Operational Definition of 'Social Role' in Online Community. System Sciences, 2009. HICSS '09. 42nd Hawaii International Conference on, 5-8 Jan. 2009 2009. 1-11.

Goffman, E. (1959). The Presentation of Self in Everyday Life, Doubleday.

Gravetter, F. and Wallnau, L. (2014). Essentials of statistics for the behavioral sciences, Belmont, Wadsworth.

Gronroos, C. (1990), "Relationship approach to marketing in service contexts: The marketing and organizational behavior interface". Journal of Business Research, Vol. 20 No 1, pp. 3-11.

Grönroos, C. (2006), "Adopting a service logic for marketing". Marketing Theory, Vol. 6 No 3, pp. 317-333.

Grönroos, C. (2008), "Service logic revisited: who creates value? And who co-creates?". European Business Review, Vol. 20 No 4, pp. 298-314.

Grönroos, C. and Ravald, A. (2011), "Service as business logic: implications for value creation and marketing". Journal of Service Management, Vol. 22 No 1, pp. 5-22.

Grönroos, C. and Voima, P. (2013), "Critical service logic: making sense of value creation and co-creation". Journal of the Academy of Marketing Science, Vol. 41 No 2, pp. 133-150.

Guan, X., Xie, L., Shen, W.-G. and Huan, T.-C. (2021), "Are you a tech-savvy person? Exploring factors influencing customers using self-service technology". Technology in Society, Vol. 65 No 101564.

Heinonen, K., Strandvik, T., Mickelsson, K. J., Edvardsson, B., Sundström, E. and Andersson, P. (2010), "A customer-dominant logic of service". Journal of Service Management, Vol. 21 No 4, pp. 531-548.

Hilton, T., Hughes, T., Little, E. and Marandi, E. (2013), "Adopting self-service technology to do more with less". Journal of Services Marketing, Vol. 27 No 1, pp. 3-12.

Hsu, P.-F., Nguyen, T. K. and Huang, J.-Y. (2021), "Value co-creation and co-destruction in self-service technology: A customer's perspective". Electronic Commerce Research and Applications, Vol. 46 No 101029.

Hunt, S. D. (1976), "The Nature and Scope of Marketing". Journal of Marketing, Vol. 40 No 3, pp. 17-28.

Jaworski, B. and Kohli, A. K. 2006. Co-creating the voice of the customer. In: LUSCH, R. F.andVARGO, S. L. (eds.) The service dominant logic of marketing: Dialog, debate and directions. New York: M.E. Sharpe.

Kelly, P., Lawlor, J. and Mulvey, M. (2017), "Customer Roles in Self-Service Technology Encounters in a Tourism Context". Journal of Travel \& Tourism Marketing, Vol. 34 No 2, pp. 222-238. 
Knote, R., Janson, A., Söllner, M. and Leimeister, J. M. (2021), "Value co-creation in smart services: a functional affordances perspective on smart personal assistants". Journal of the Association for Information Systems, Vol. 22 No 2, pp. 5.

Lee, Y. H., Hsiao, C. and Chen, Y. C. (2017), "Linking positive psychological capital with customer value cocreation". International Journal of Contemporary Hospitality Management, Vol. 29 No 4, pp. 1235-1255.

Liljander, V., Gillberg, F., Gummerus, J. and Van Riel, A. (2006), "Technology readiness and the evaluation and adoption of self-service technologies". Journal of Retailing and Consumer Services, Vol. 13 No 3, pp. 177191.

Lin, I. Y. and Mattila, A. S. (2021), "The Value of Service Robots from the Hotel Guest's Perspective: A MixedMethod Approach". International Journal of Hospitality Management, Vol. 94 No 102876.

Lorenzo-Romero, C., Andrés-Martínez, M.-E., Cordente-Rodríguez, M. and Gómez-Borja, M. Á. (2021), "Active Participation of E-Consumer: A Qualitative Analysis From Fashion Retailer Perspective". SAGE Open, Vol. 11 No 1, pp. 2158244020979169.

Lusch, R., Vargo, S. and Tanniru, M. (2010), "Service, value networks and learning". Journal of the Academy of Marketing Science, Vol. 38 No 1, pp. 19-31.

Lusch, R. F. and Vargo, S. L. (2014). Service-Dominant Logic: Premises, Perspectives, Possibilities, Cambridge University Press.

Lysonski, S. J. and Johnson, E. M. (1983), "The Sales Manager As a Boundary Spanner: A Role Theory Analysis". Journal of Personal Selling \& Sales Management, Vol. 3 No 2, pp. 8-21.

Mccoll-Kennedy, J. R., Vargo, S. L., Dagger, T. and Sweeney, J. C. 2009. Customers as Resource Integrators: Styles of Customer Co-creation. Naples Forum on Services: Service-Dominant Logic,Service Science, and Network Theory. Capri.

Merrilees, B. (2016), "Interactive brand experience pathways to customer-brand engagement and value cocreation". Journal of Product and Brand Management, Vol. 25 No 5, pp. 402-408.

Merz, M. A., Zarantonello, L. and Grappi, S. (2018), "How valuable are your customers in the brand value cocreation process? The development of a Customer Co-Creation Value (CCCV) scale". Journal of Business Research, Vol. 82 No 79-89.

Meuter, M. L. and Bitner, M. J. Self-service technologies: extending service frameworks and identifying issues for research. American Marketing Association. Conference Proceedings, 1998. American Marketing Association, 12.

Meuter, M. L., Bitner, M. J., Ostrom, A. L. and Brown, S. W. (2005), "Choosing Among Alternative Service Delivery Modes: An Investigation of Customer Trial of Self-Service Technologies". Journal of Marketing, Vol. 69 No 2, pp. 61-83.

Meuter, M. L., Ostrom, A. L., Roundtree, R. I. and Bitner, M. J. (2000), "Self-Service Technologies: Understanding Customer Satisfaction with Technology-Based Service Encounters". Journal of Marketing, Vol. 64 No 3, pp. 50-64.

Michel, S., Brown, S. W. and Gallan, A. S. (2008), "Service-Logic Innovations: How to Innovate Customers, Not Products". California Management Review, Vol. 50 No 3, pp. 49-65.

Moeller, S., Ciuchita, R., Mahr, D., Odekerken-Schröder, G. and Fassnacht, M. (2013), "Uncovering Collaborative Value Creation Patterns and Establishing Corresponding Customer Roles". Journal of Service Research, Vol. 16 No 4, pp. 471-487. 
Normann, R. (2001). Reframing Business: When the Map Changes the Landscape, Wiley.

Payne, A., Storbacka, K., Frow, P. and Knox, S. (2009), "Co-creating brands: Diagnosing and designing the relationship experience". Journal of Business Research, Vol. 62 No 3, pp. 379-389.

Payne, A. F., Storbacka, K. and Frow, P. (2008), "Managing the co-creation of value". Journal of the Academy of Marketing Science, Vol. 36 No 1, pp. 83-96.

Prahalad, C. K. and Ramaswamy, V. (2004), "Co-creation experiences: The next practice in value creation". Journal of Interactive Marketing, Vol. 18 No 3, pp. 5-14.

Prebensen, N. K. and Xie, J. (2017), "Efficacy of co-creation and mastering on perceived value and satisfaction in tourists' consumption". Tourism Management, Vol. 60 No Supplement C, pp. 166-176.

Preikschas, M. W., Cabanelas, P., Rüdiger, K. and Lampón, J. F. (2017), "Value co-creation, dynamic capabilities and customer retention in industrial markets". Journal of Business \& Industrial Marketing, Vol. 32 No 3, pp. 409-420.

Quinn, J. B., Doorley, T. L. and Paquette, P. C. (1990), "Beyond Products: Services-Based Strategy". Harvard Business Review, Vol. 68 No 2, pp. 64-68.

Rihova, I., Buhalis, D., Moital, M. and Beth Gouthro, M. (2013), "Social layers of customer-to-customer value co-creation". Journal of Service Management, Vol. 24 No 5, pp. 553-566.

Saarijärvi, H., Kannan, P. K. and Kuusela, H. (2013), "Value co-creation: theoretical approaches and practical implications". European Business Review, Vol. 25 No 1, pp. 6-19.

Sandström, S., Edvardsson, B., Kristensson, P. and Magnusson, P. (2008), "Value in use through service experience". Managing Service Quality: An International Journal, Vol. 18 No 2, pp. 112-126.

Sekaran, U. (2006, p.203). Research Methods For Business, New Delhi, Wiley.

Skålén, P., Gummerus, J., Koskull, C. V. and Magnusson, P. R. (2015), "Exploring value propositions and service innovation: a service-dominant logic study". Journal of the Academy of Marketing Science, Vol. 43 No 137158.

Solomon, M. R., Surprenant, C., Czepiel, J. A. and Gutman, E. G. (1985), "A Role Theory Perspective on Dyadic Interactions: The Service Encounter". Journal of Marketing, Vol. 49 No 1, pp. 99-111.

Terblanche, N. S. (2014). Some theoretical perspectives of co-creation and co-production of value by customers.

Trochim, W. M. and Donnelly, J. P. (2006). The research methods knowledge base, Cincinnati OH, Atomic Dog.

Vargo, S. L. and Lusch, R. F. (2008), "Why "service"?". Journal of the Academy of Marketing Science, Vol. 36 No 1, pp. 25-38.

Vargo, S. L., Maglio, P. P. and Akaka, M. A. (2008), "On value and value co-creation: A service systems and service logic perspective". European Management Journal, Vol. 26 No 3, pp. 145-152.

Verhoef, P. C., Lemon, K. N., Parasuraman, A., Roggeveen, A., Tsiros, M. and Schlesinger, L. A. (2009), "Customer Experience Creation: Determinants, Dynamics and Management Strategies". Journal of Retailing, Vol. 85 No 1, pp. 31-41.

Yi, Y. and Gong, T. (2013), "Customer value co-creation behavior: Scale development and validation". Journal of Business Research, Vol. 66 No 9, pp. 1279-1284. 